\title{
TECHNO-ECONOMIC ASSESSMENT OF TRANSFORMING SORGHUM BAGASSE INTO BIOETHANOL FUEL IN NIGERIA: 1 - PROCESS MODELLING, SIMULATION, AND COST ESTIMATION
}

\author{
AJAYI OLUFUNMILOLA OYENIKE ${ }^{1}$, ONIFADE, KOLAWOLE RASHEED ${ }^{2}$, \\ ONADEJI ABIODUN ${ }^{3}$, OYEGOKE TOYESE $* 2,4$ \\ ${ }^{1}$ Department of Chemical Engineering, Federal University of Technology Minna, Nigeria \\ ${ }^{2}$ Department of Chemical Engineering, Faculty of Engineering, Ahmadu Bello University \\ Zaria, Nigeria \\ ${ }^{3}$ Department of Water Resource \& Environmental Engineering, Faculty of Engineering, \\ Ahmadu Bello University Zaria, Nigeria \\ ${ }^{4}$ Chemistry Laboratory, ENS, Lyon University, Lyon, France
}

\begin{abstract}
Apart from the environmental threats posed by fossil fuel due to emissions of greenhouse gases (majorly $\mathrm{CO}_{2}$ ), Nigeria's economy's continuous reliance on only one source of fuel production is unsustainable, hence, the need to consider diversification and alternative sources of energy generation and fuel production. This work aims to model and simulate the process of transforming sorghum bagasse into a fuel grade bioethanol via the use of Aspen HYSYS and MATLAB for the development and evaluation of cost implications and demand of the concerned plant studied. The study of process plant models shows that $189 \mathrm{~g}$ of fuel grade bioethanol will be obtainable from a kilogram of sorghum bagasse based on the condition employed in the modeling of the process. Cost analysis indicates that it would require a capital and operation cost worth of $\$ 1.92$ and $\$ 0.83$, respectively, to produce a liter of fuel grade bioethanol from sorghum bagasse.
\end{abstract}

Keywords: sorghum, bagasse, modeling, bioethanol, biofuels, process economics

\section{INTRODUCTION}

One of the most potent tools in combating vehicular pollution is Bioethanol. It is an alcohol produced from the process of fermenting Sugar, starch or cellulosic biomass. It contains 35\% oxygen, which helps in the complete combustion of fuel and turn, enhances the reduction of harmful tailpipe emissions [1].

Bioethanol is experiencing rapid growth in industrialization and also emerging as a global market, which is becoming increasingly crucial by drawing both public and scientific attention basically due to its attractive properties, fluctuating price of oil, and the need for increased energy security. The use of bioethanol is essential to reduce the reliance on non-renewable energy resources like oil and coal [2].

Notable among other reasons to look beyond the oil and gas and delve into an alternate source of energy production is the environmental threats posed by fossil fuels which are associated with the emissions of greenhouse gases (majorly $\mathrm{CO}_{2}$ ) which are connected to climate change and other disastrous effects on the earth and its habitants [3,

\footnotetext{
* Corresponding author, email: oyegoketoyese@gmail.com

(C) 2020 Alma Mater Publishing House
} 
4]. According to Galadima et al. [5], about $75 \%$ of the Carbon dioxide made by humans was from the burning of fossil fuels. He also reported that Nigeria is contributing the most significant portion of this emission in SubSaharan Africa, and particularly, the second world's biggest gas flarer.

For over a century, one of the significant sources of energy in the world is the production of oil and gas. Since the discovery of crude oil in the Delta region in the mid-1950s, it has gradually taken over the heart of Nigeria's economy and gaining ground as the primary source of energy and revenue to the country, side-lining other sectors in the process [6]. Oil and gas currently account for approximately $90 \%$ of the country's total government revenues and foreign exchange benefits.

Currently, these commodities accounted for over $90 \%$ of both foreign exchange benefits and total government revenues. Total and continuous reliance on this crude oil only spells doom for Nigeria's economy especially, considering the recent global crash in the price of crude oil, which has, in turn, negatively affected the economic strength of the Nigerian people. Also, the current reserves of 36.22 billion barrels and 181 trillion cubic feet of oil and gas could only last for the next 35 to 40 years. This only implies that the days of the consistent flow of oil and gas are numbered, which could be attributed to the rapid increase in population and increased rate of energy consumption, among other factors [7]. Researches have been looking into the feasibility of establishing biofuel refineries in Nigeria. Some of these works are bioethanol production from cassava [8], sugarcane bagasse [9], molasses [10], combine sugarcane-bagasse-juice [11] and others [12]. However, no work has looked into the economics of employing the use of sorghum bagasse for the production of biofuel (bioethanol in particular).

This study seeks to model, simulate and investigate cost implication of establishing or building a process plant set up for the transformation of sorghum bagasse into bioethanol fuel in Nigeria with the aid of Aspen HYSYS and MATLAB application software. This task entailed process flowsheet development, material, and energy analysis, costing of process plant equipment, estimation of total capital investment, and cost of manufacturing/production in Nigeria.

\section{MATERIALS AND METHODS}

\subsection{Study framework}

The approach adopted in this research can be illustrated diagrammatically in Figure 1. It begins by sketching the block flow diagram for the proposed process and concludes by presenting the material and energy analysis, cost estimation, and the developed process flow diagram. Total capital investment estimation and cost of manufacturing were also factored into the cost estimation.

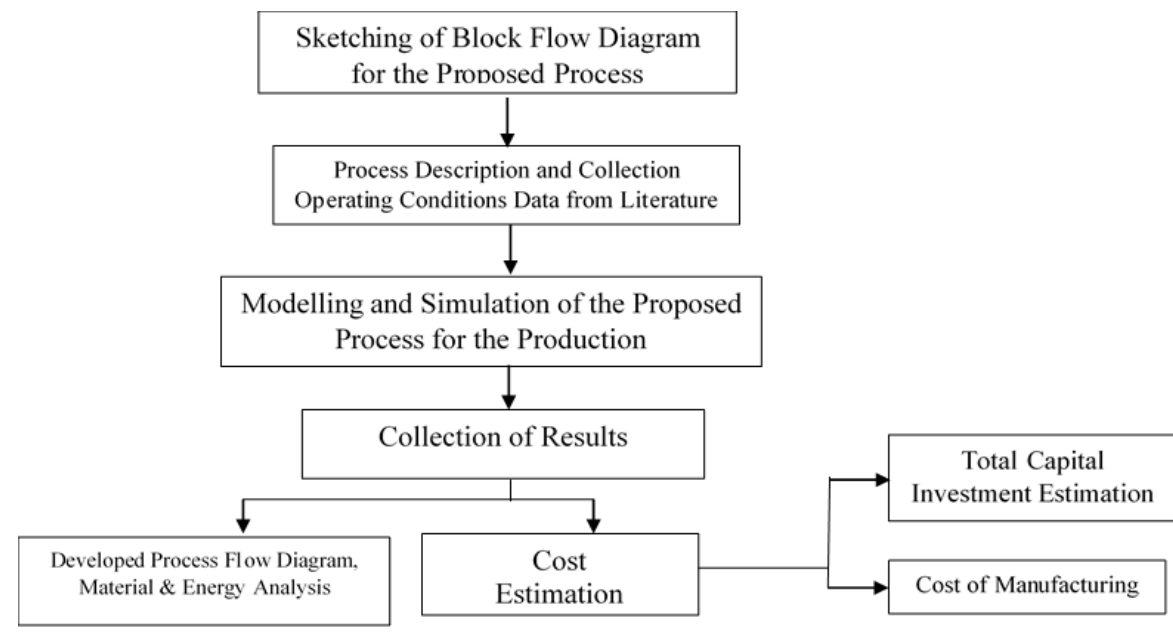

Fig. 1. Research approach framework.

\subsection{Process description}

Bioethanol production begins with a crushed and pre-treated sweet sorghum stalk feed whose compositions are presented in Table 1. The feed in the modeled plant was extracted to remove juice from sorghum stalk. The 
resulting product of extraction composing of sucrose, hemicellulose, and cellulose was hydrolyzed in different reactors.

Table 1. Feedstock composition and operating conditions.

\begin{tabular}{|l|c|}
\hline Component Name & Value \\
\hline Cellulose* & 0.07 \\
\hline Hemicellulose* & 0.04 \\
\hline Lignin* & 0.03 \\
\hline Sucrose & 0.10 \\
\hline $\mathrm{H}_{2} \mathrm{O}$ & 0.73 \\
\hline Glucose (as Dextrose) & 0.02 \\
\hline Fructose (as Dextrose) & 0.02 \\
\hline Vapour / Phase Fraction & 0.00 \\
\hline Temperature $\left[{ }^{\circ} \mathrm{C}\right]$ & 25.00 \\
\hline Pressure $[$ atm $]$ & 2.00 \\
\hline Mass Flow $[\mathrm{kg} / \mathrm{h}]$ & $50,000.00$ \\
\hline
\end{tabular}

Adapted from Gnansounou et al. [13], Kim \& Day [14], Mamma et al. [15], Sergio et al. [16 ].

After hydrolysis, the fermentable sugars were fermented. The raw bioethanol produced was then purified. The entire process is diagrammatically summarized in the blocks flow diagram presented in Figure 2, which was employed to modeled and simulated using Aspen HYSYS 8.0 following the procedures presented in Figure 3.

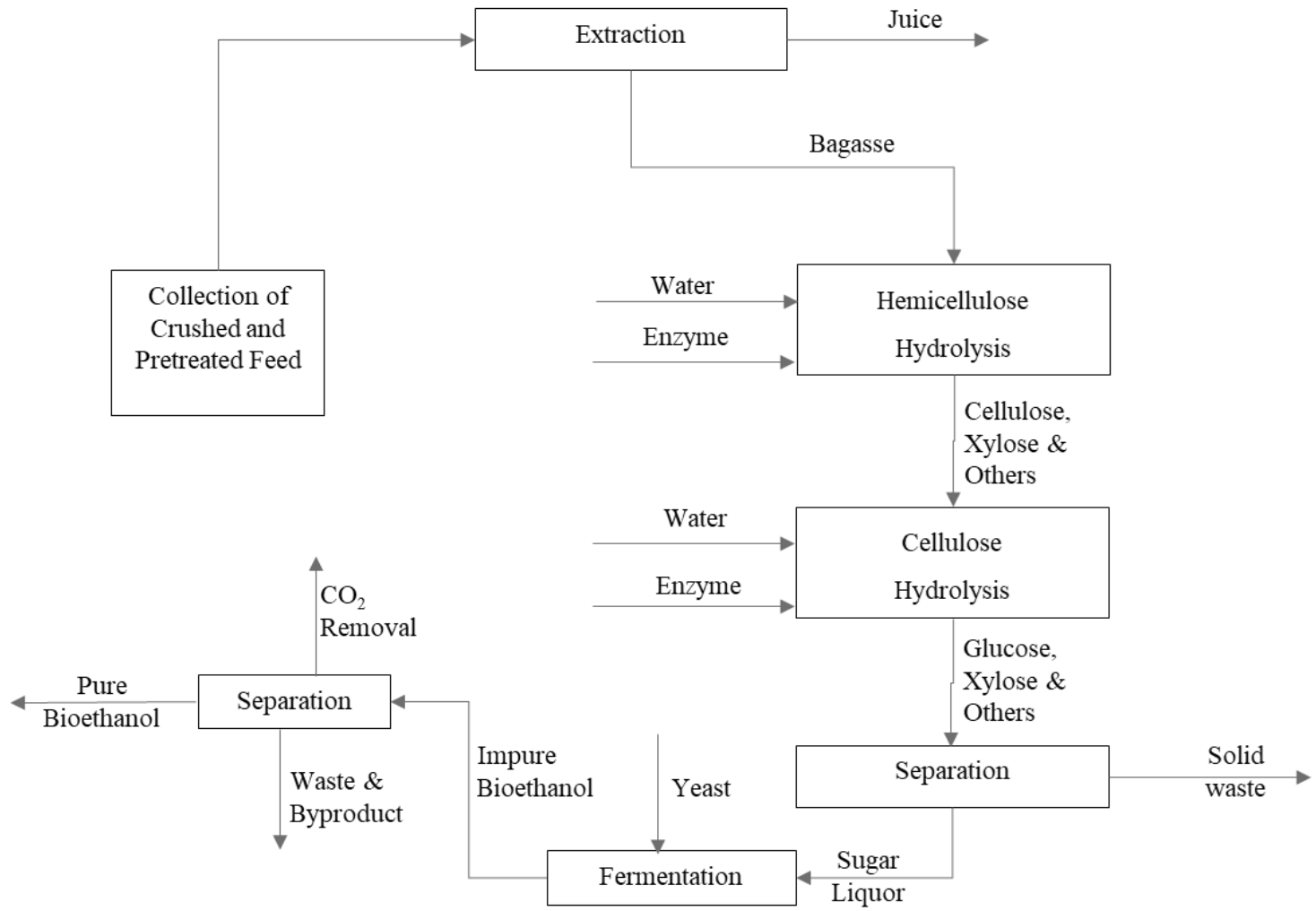

Fig. 2. Block flow diagram for the conversion of sorghum bagasse to bioethanol fuel.

The extracted sorghum juice from hydro-cyclones was sold out for sugar production while the bagasse was used for bioethanol production. In this process, the extracted bagasse was hydrolyzed in the presence of enzymes at the temperature of $50^{\circ} \mathrm{C}$ to glucose and xylose. The fermentable sugar stream was then prepared to meet the operating conditions and then passed to the fermentation reactor, where sugar was converted to bioethanol and carbon dioxide in the presence of an enzyme called yeast. The raw products are then purified in a flash, absorber, and distillation columns. 


\subsection{Process modelling}

In this research, a process simulation approach has been adopted using Aspen HYSYS 8.0 process simulator, MATLAB and Microsoft Excel 2013 in modeling and simulating different process flow diagrams for different process technologies for the production of bioethanol from sorghum bagasse. Aspen HYSYS is a robust simulator with a considerable measure of accuracy [17]. In simulating the process technology, the stage-wise procedures illustrated diagrammatically in Figure 3 were employed.

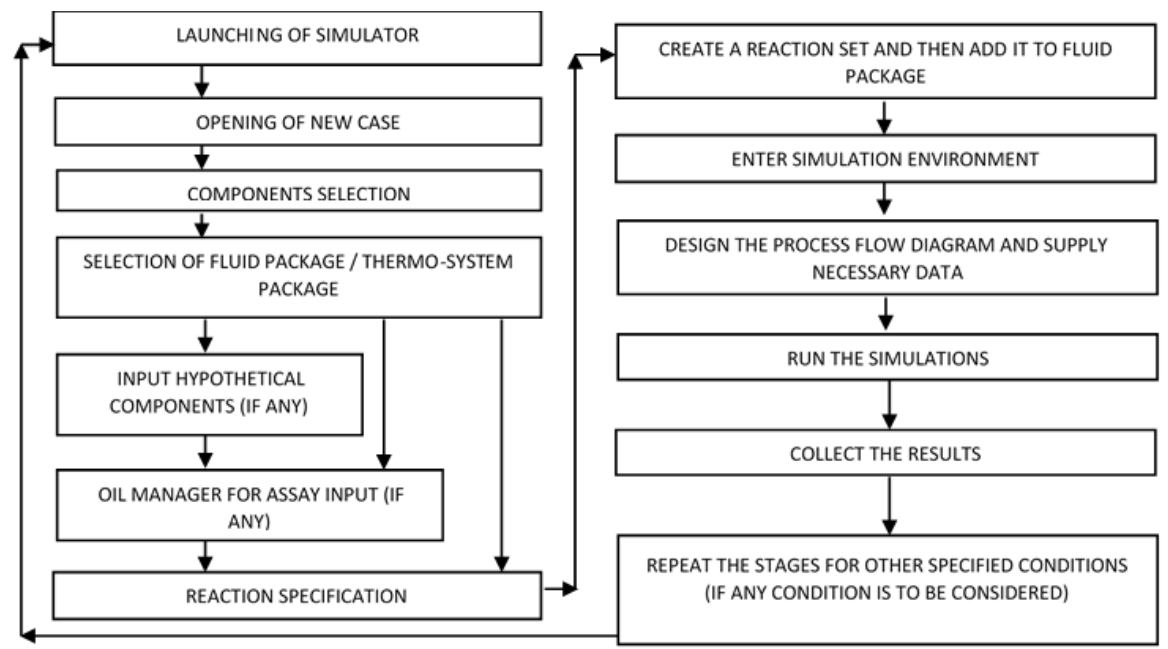

Fig. 3. Flow chart for simulating a process in Aspen HYSYS [11, 18].

\subsubsection{Plant simulations assumptions}

The following assumptions were made for the plant simulations:

- The feedstock is crushed, washed, and pre-treated with Phosphoric acid and Sodium hydroxide.

- One hundred polymeric units have been assumed for the cellulose model.

- Cooling water is fed at $25{ }^{\circ} \mathrm{C}$ and $1 \mathrm{~atm}$.

Other operating conditions that might not be presented here in this report for any unit operations and processes of interest can be found in the report of Olateju [19].

\subsubsection{Simulation components}

In modeling the process plants, itemized in Table 2 are the components selected from the Aspen HYSYS components library and those that were hypothetically modeled, which were otherwise known as hypothetical components not induced in the library. They were represented by specifying their typical boiling point, molecular weight, density, diameter, molecular formula from literature while other properties were estimated with the aid of Aspen HYSYS estimator. These are presented in Table 3.

Table 2. Aspen HYSYS pure and hypothetical components involved in this process.

\begin{tabular}{|l|l|l|}
\hline Name & Chemical Formula & Process Application \\
\hline Carbon dioxide & $\mathrm{CO}_{2}$ & Fermentation product \\
\hline Ethanol & $\mathrm{C}_{2} \mathrm{H}_{6} \mathrm{O}$ & Fermentation product \\
\hline Glucose (or Dextrose) & $\mathrm{C}_{6} \mathrm{H}_{12} \mathrm{O}_{6}$ & Hydrolysis product \\
\hline Water & $\mathrm{H}_{2} \mathrm{O}$ & For hydrolysis and washing \\
\hline Sucrose & $\mathrm{C}_{12} \mathrm{H}_{22} \mathrm{O}_{11}$ & Feedstock \\
\hline Xylose & $\mathrm{C}_{5} \mathrm{H}_{10} \mathrm{O}_{5}$ & Hydrolysis product \\
\hline Cellulose & $\left(\mathrm{C}_{6} \mathrm{H}_{10} \mathrm{O}_{5}\right)_{\mathrm{n}}$ & Feedstock \\
\hline Hemicellulose & $\left(\mathrm{C}_{5} \mathrm{H}_{8} \mathrm{O}_{4}\right)_{n}$ & Feedstock \\
\hline Lignin & $\left(\mathrm{C}_{31} \mathrm{H}_{34} \mathrm{O}_{11}\right)_{\mathrm{n}}$ & Feedstock \\
\hline Enzyme & $\mathrm{CH}_{1.57} \mathrm{~N}_{0.29} \mathrm{O}_{0.31} \mathrm{~S}_{0.007}$ & Enzymatic hydrolysis \\
\hline Furfural & $\mathrm{C}_{5} \mathrm{H}_{4} \mathrm{O}_{2}$ & By-product of hydrolysis \\
\hline Yeast & $\mathrm{Undefined}^{*}$ & Fermentation bacteria \\
\hline Z. mobilis & $\mathrm{CH}_{1.8} \mathrm{O}_{0.5} \mathrm{~N}_{0.2}$ & Fermentation bacteria \\
\hline & &
\end{tabular}


Note: * was modeled as Z. mobilis since Yeast is a unicellular fungus and not a chemical compound; hence, it has no chemical formula.

Table 3. Hypothetical components and their properties.

\begin{tabular}{|c|c|}
\hline Component & Specified Properties \\
\hline Xylose & $\begin{array}{l}\text { Chemical Formula: } \mathrm{C}_{5} \mathrm{H}_{10} \mathrm{O}_{5} \\
\text { NBP, Ideal Liquid Density, Molecular Weight }{ }^{(\mathrm{E})}\end{array}$ \\
\hline Cellulose & $\begin{array}{l}\text { Chemical Formula: }\left(\mathrm{C}_{6} \mathrm{H}_{10} \mathrm{O}_{5}\right)_{\mathrm{n}} \text { where } \mathrm{n}=100 \text { units } \\
\text { Density, Molecular Weight }\end{array}$ \\
\hline Hemicellulose & $\begin{array}{l}\text { Chemical Formula: }\left(\mathrm{C}_{5} \mathrm{H}_{8} \mathrm{O}_{4}\right)_{n} \text { where } \mathrm{n}=10 \text { units } \\
\text { Density }^{(\mathrm{A})}, \text { Molecular Weight } \\
\end{array}$ \\
\hline Lignin & $\begin{array}{l}\text { Chemical Formula: }\left(\mathrm{C}_{31} \mathrm{H}_{34} \mathrm{O}_{11}\right)_{\mathrm{n}} \text { where } \mathrm{n}=10 \text { units } \\
\text { Density }^{(\mathrm{A})}, \text { Molecular Weight } \\
\end{array}$ \\
\hline Enzyme & $\begin{array}{l}\text { Modeled as Glucose, Chemical Formula: } \mathrm{CH}_{1.57} \mathrm{~N}_{0.29} \mathrm{O}_{0.31} \mathrm{~S}_{0.007} \\
\text { Density, Molecular Weight }{ }^{(\mathrm{E})} \text {, Diameter }{ }^{(\mathrm{A})}\end{array}$ \\
\hline Z. mobilis & $\begin{array}{l}\text { Modeled as Glucose, Chemical Formula: } \mathrm{CH}_{1.8} \mathrm{O}_{0.5} \mathrm{~N}_{0.2} \\
\text { Density, Molecular Weight }{ }^{\mathrm{E})}, \text { Diameter }^{(\mathrm{A})}\end{array}$ \\
\hline Cellubiose & $\begin{array}{l}\text { Chemical Formula: }\left(\mathrm{C}_{6} \mathrm{H}_{10} \mathrm{O}_{5}\right)_{\mathrm{n}} \text { where } \mathrm{n}=200 \text { units } \\
\text { Density, Molecular } \mathrm{Weight}^{(\mathrm{E})}, \text { Diameter }^{(\mathrm{A})}\end{array}$ \\
\hline
\end{tabular}

Note: ${ }^{(\mathrm{E})}$ represent estimated property, ${ }^{(\mathrm{A})}$ represent assumed property

\subsubsection{Material and energy analysis for production process}

With the aid of Aspen HYSYS 8.0 in-built command, the following process variables were determined from the material and energy balance analysis:

- Energy constraint for both heating and cooling duties for different units;

- Material resource that would be needed for effective and efficient production;

- Equipment Specification for costing basis and bioethanol production quantity.

\subsection{Cost estimation}

The results of material and energy analysis of the modeled and simulated process technologies were used to determine the size and cost process of equipment, after which the resulting total cost of purchasing equipment for the different respective technologies was determined using the procedure in subsection 2.4.2. Furthermore, both total capital investment and the cost of manufacturing were evaluated using the approach in subsections 2.4.3 and 2.4.4, respectively.

\subsubsection{Project parameters and assumptions}

In assessing the techno-economic feasibility study of the processes, the following project parameters and assumptions presented in Table 4 were employed in the different profitability analysis.

Table 4. Project parameters and assumptions.

\begin{tabular}{|c|c|}
\hline Parameters & Values \\
\hline Working time & 24 hours per day, for 335 days per year \\
\hline Raw material ${ }^{(1)}$ & Sorghum stalk $50,000 \mathrm{~kg}$ per hour for $26 \mathrm{NGN} / \mathrm{kg}$ \\
\hline Discount rate & $10.00 \%$ \\
\hline Working capital rate ${ }^{(2)}$ & $5.00 \%$ per year \\
\hline Proposed product price & $0.50-0.67 \mathrm{~S} / \mathrm{L}(100-133 \mathrm{NGN} / \mathrm{L})$ \\
\hline Currency conversion rate & 199 NGN/\$ (2016), 365 NGN/\$ (2020) \\
\hline Tax rate & $20.00 \%$ per year \\
\hline The economic life of the project & 25.00 years \\
\hline Depreciation method $^{(3)}$ & Straight Line \\
\hline Depreciation period & 10 years \\
\hline Profit & $6 \%$ \\
\hline
\end{tabular}

Note: ${ }^{1}$ Nationa Beaurue of Statistics 2012, ${ }^{2}$ Richardson and Coulson 20; (2005) [20]

\subsubsection{Plant equipment costing}

Using Marshall and Swiss cost correlation and indices with equation (1) [21] with the aid of Microsoft Excel 2013, each unit equipment cost were estimated as $C_{i}$ while the resulting cost was escalated respectively using the equation (2) to evaluate an updated cost of each unit equipment as $C_{x}$.

$$
C_{i}=C_{o} * S^{n}
$$




$$
C_{x}=C_{i} *\left(M S_{x} / M S_{n}\right)
$$

where $C_{i}$ are cost as at $i$ year, $C_{o}$ are bare cost at $i$ year, $C_{x}$ are escalated cost as at $x$ year, $S$ are size of equipment, $n$ are cost index, $M S$ are marshall and swiss cost index at $n$ and $x$ year.

\subsubsection{Total capital investment estimation}

The estimation of the capital investment was carried out using the data collected from the sources shown in Table 5.

Table 5. Sources of data for total capital investment estimation.

\begin{tabular}{|l|l|}
\hline Items & Source of data \\
\hline Direct Plant Cost & \\
\hline Purchased cost of equipment & Sinnott [21], Sieder and Seader [22], Max et al., [23] \\
\hline Equipment installation cost & Sinnott [21] \\
\hline Piping installation cost & Sinnott [21] \\
\hline Electricity installation cost & Sinnott [21] \\
\hline Instrumentation and control & Sinnott [21] \\
\hline Building and services & Sinnott [21] \\
\hline Excavation and site preparation & Sinnott [21] \\
\hline Auxiliaries/service facilities & Sinnott [21] \\
\hline Land survey \& cost & Sinnott [21] \\
\hline Indirect Plant Cost & \\
\hline Field \& construction expense & Sinnott [21] \\
\hline Engineering \& supervision & Sinnott [21] \\
\hline Other Plant Cost & \\
\hline Contractor's fee, overhead, and profit & Sinnott [21] \\
\hline Contingency & Sinnott [21] \\
\hline Working Capital & Sinnott [21] \\
\hline
\end{tabular}

Using factorial method and purchased equipment cost [21] with the aid MATLAB program code documented in Olateju [19] using equations (3) to (10), total capital investment was estimated as:

$$
\begin{gathered}
\text { Escalated Purchased Equipment Cost, PCE }=\text { input } \\
\text { Direct Plant Cost, } D P C=2.93 * P C E \\
\text { Indirect Plant Cost, } I P C=1.76 * D P C \\
\text { Total Plant Cost, TPC }=D P C+I P C \\
\text { Other Plant Costs, OPC }=0.15 * T P C \\
\text { Fixed Capital Investment, FCI }=\text { TPC }+ \text { OPC } \\
\text { Working Capital, } W C=0.05 * F C I \\
\text { Total Capital Investment, TCI }=F C I+W C
\end{gathered}
$$

\subsubsection{Cost of manufacturing estimation}

The estimation for the cost of manufacturing was done with the use of relevant data sourced from the references presented in Table 6 for each item.

Table 6. Sources of some data for the cost of manufacturing estimation.

\begin{tabular}{|l|l|}
\hline Items & Source of data \\
\hline Raw Material (RM) & NBS Report for 2010-2012; Furla et al., [24]. \\
\hline $\begin{array}{l}\text { Utilities Cost (UT), e.g., Cooling water, Electricity, Waste } \\
\text { management, etc. }\end{array}$ & KEDCO Bill Report, Sinnott [21], Seider \& Seader [22]. \\
\hline Plant Overhead (PO) Information & Sinnott [21] \\
\hline
\end{tabular}


Using the factorial method and case-study based cost data for raw material, operating labor and utilities costs were estimated using MATLAB. The manufacturing cost was estimated from the direct production cost, fixed manufacturing cost, and general expenses.

\section{RESULTS AND DISCUSSION}

\subsection{Process flow-sheeting output}

The process flow diagram for the bioethanol production from sorghum bagasse is presented in Figure 4, which was built with the use of the block flow diagram presented in Figure 2.

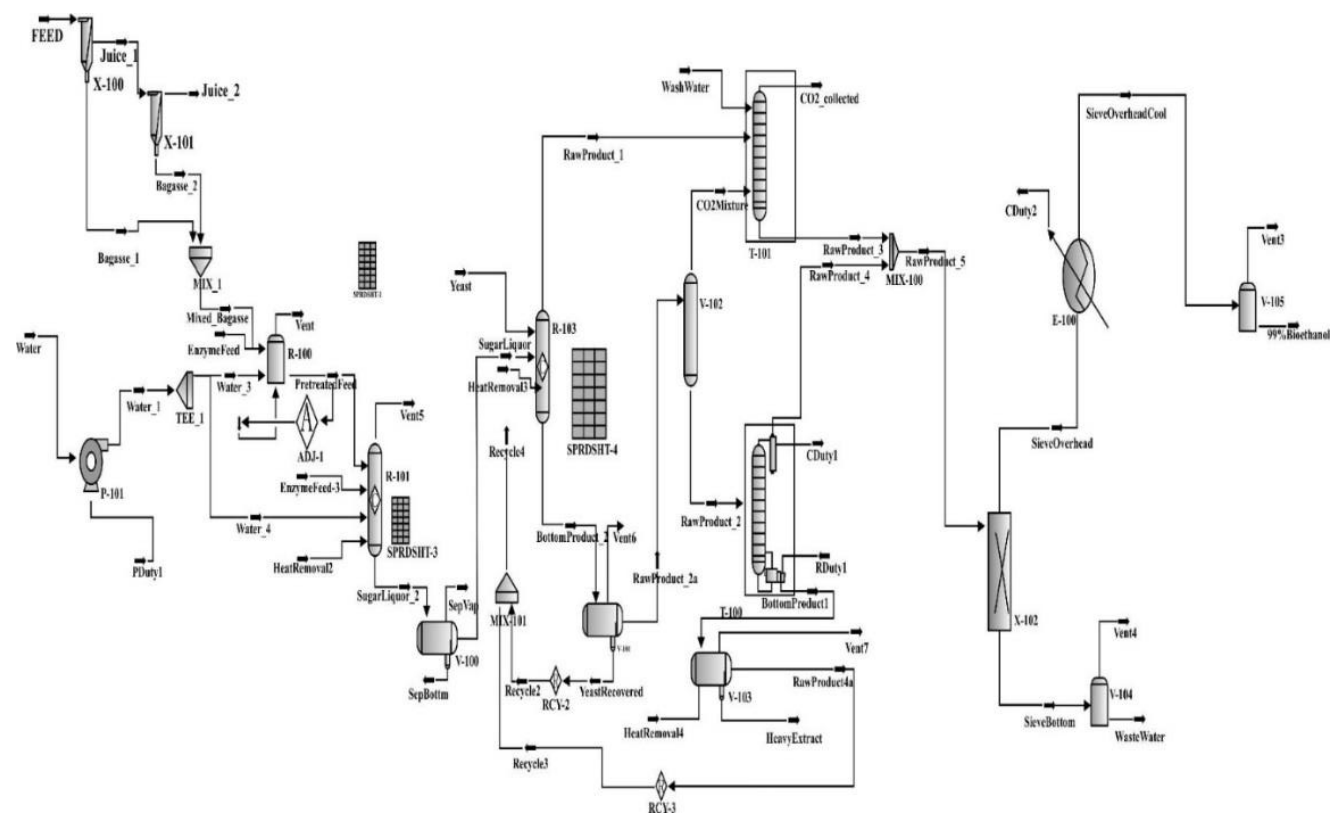

Fig. 4. PFD for bioethanol production from sorghum bagasse.

\subsection{Material analysis results}

The results of the overall material balance for the flow of materials throughout the process plant simulated are summarized and presented in Table 8 . The error of $0.00 \%$ obtained from the analysis indicated that there exists a good balance in the rate at which materials flow in $(57,817.04 \mathrm{~kg} / \mathrm{h})$ and out $(57,817.04 \mathrm{~kg} / \mathrm{h})$ of the processing units of the plant. And that the law of conservation of mass is maintained through the processes involved in the transformation.

Table 8. Results of the plant overall material balance.

\begin{tabular}{lrlr}
\hline Material Stream Inlet & Flow Rate $(\mathrm{kg} / \mathrm{h})$ & Material Stream Outlet & Flow Rate $(\mathrm{kg} / \mathrm{h})$ \\
\hline Yeast & 813.46 & Vent5 & 0.00 \\
Enzyme Feed-3 & $3,553.57$ & Vent & 0.00 \\
Enzyme Feed & $3,327.95$ & Juice_2 & 579.91 \\
Water & 50.00 & $\mathrm{CO}_{2}$ collected & $13,682.24$ \\
Feed & $50,000.00$ & Vent6 & 0.00 \\
Wash Water & 72.06 & $99 \%$ Bio-ethanol & $9,407.69$ \\
& & Vent3 & 0.00 \\
& & Waste Water & 41.51 \\
& & Vent4 & 0.00 \\
& & SepVap & 0.00 \\
& & Sep Bottm & $31,701.37$ \\
\hline
\end{tabular}




\begin{tabular}{llr}
\hline & Vent7 & 0.00 \\
& Heavy Extract & 0.00 \\
& Recycle4 & $2,404.32$ \\
\hline Material Inlet & & Material Outlet \\
\hline & Error (\%) & $57,817.04$ \\
\hline
\end{tabular}

Moreover, findings from this study reveal that $9,408 \mathrm{~kg}$ of fuel grade bioethanol was produced from the use of $50,000 \mathrm{~kg}$ of sorghum bagasse, $6882 \mathrm{~kg}$ of enzyme, and $813 \mathrm{~kg}$ of yeast in an hour. This implies that $189 \mathrm{~g}$ of fuel grade bioethanol will always be obtained from a kilogram of sorghum bagasse, which was found to be lower compared to combine sugarcane-bagasse-juice, which was reported by Oyegoke \& Dabai [11] as $292 \mathrm{~g} / \mathrm{kg}$ $(14,618 / 50,000 \mathrm{~kg} / \mathrm{kg})$. However, it was found to be greater than that reported by Abemi et al. [10] as $117 \mathrm{~g} / \mathrm{kg}$ $(8,238 / 70,000 \mathrm{~kg} / \mathrm{kg})$ for the use of molasses.

\subsection{Energy analysis results}

The results of the overall energy balance for the simulated plant are presented in Table 9, which displayed the flow of energy across the units of process plant modeled. The energy analysis findings indicate that there exists a good balance when total inflow and outflow of energy across the units of the modeled plant compared except for the slight error of $0.06 \%$ which was due to the hypothetical component introduced in the modeling of the plant when some component was found missing in the simulator component libraries for compounds [10, 11].

Table 9. Results of plant overall energy balance.

\begin{tabular}{lcr}
\hline Energy Inlet & Flow Rate $(\mathrm{kJ} / \mathrm{h})$ x $10^{8}$ Energy Outlet & Flow Rate $(\mathrm{kJ} / \mathrm{h}) \times 10^{8}$ \\
\hline Yeast & 0.0000340 Vent5 & 0.00 \\
Heat Removal3 & -0.170 Vent & 0.00 \\
Enzyme Feed-3 & 0.00 Juice_2 & -0.0477 \\
Heat Removal2 & -1.09 CO2_collected & -0.917 \\
Enzyme Feed & 0.00 Vent6 & 0.00 \\
Heat Removal1 & $-0.052099 \%$ Bio ethanol & -0.568 \\
Water & 0.00 Vent3 & 0.00 \\
PDuty1 & 0.0000000443 Waste Water & -0.0064 \\
Feed & -0.0899 Vent4 & 0.00 \\
WashWater & -0.0114 SepVap & 0.00 \\
HeatRemoval4 & -0.008 .93 SepBottm & 0.206 \\
RDuty1 & 7.66 Vent7 & 0.00 \\
& Heavy Extract & 0.00 \\
& CDuty2 & 0.095 \\
& CDuty1 & 7.56 \\
\hline Energy Inlet & Recycle4 & -0.0915 \\
\hline & E.24Energy Outlet & 6.23 \\
\hline
\end{tabular}

The study reveals that the plant energy flow in, which represents the total amount of heat that flows into the plant, is worth 624 million $\mathrm{kJ}$ per hour. The value was found to be lower compared to the obtained as $1.08 \mathrm{billion} \mathrm{kJ} / \mathrm{h}$ and by Oyegoke \& Dabai [11] for the use of combined sugarcane-bagasse-juice.

The total purchase cost of equipment was estimated to be 9 million dollars, where the reactor cost proved to contribute an alarming approximately $95.7 \%$ of the entire cost. In contrast, the cost of molecular sieve made the least contribution to the total costs. The total purchase cost of equipment was found to be equivalent to the cost reported for the use of combined sugarcane-bagasse-juice in the report of Oyegoke and Dabai [11].

\subsection{Plant equipment costing}


The results obtained from the costing (in United States Dollars (\$)) of the plants' equipment are presented in Table 10.

Table 10. Results of plant equipment costing.

\begin{tabular}{lrr}
\hline Descriptions & Purchase Cost (\$) & Escalated Purchase Cost \\
\hline Cost of hydro-cyclone & $2,788.21$ & $4,129.81$ \\
Cost of vessels & $181,123.87$ & $248,933.94$ \\
Reactor cost & $6,233,430.37$ & $8,567,133.65$ \\
Column tray \& tower cost & $25,127.45$ & $34,534.79$ \\
Cost of molecular sieve & 711.58 & $1,053.98$ \\
Cost of other process facilities & $69,773.80$ & $103,363.66$ \\
Total cost & $6,512,955.28$ & $8,959,149.83$ \\
\hline
\end{tabular}

\subsection{Total Capital Investment Estimation}

The estimation of the total capital investment is presented in Table 11, while Table 12 presents the total capital investment adapted from existing literature.

Table 11: Results for plant total capital investment.

\begin{tabular}{llr}
\hline Description & Symbol & Amount (\$) \\
\hline Purchased Cost of Equipment & PCE & $8,960,000$ \\
Direct Plant Cost & DPC & $26,300,000$ \\
Indirect Plant Cost & IPC & $15,800,000$ \\
Total Plant Cost & TPC & $42,000,000$ \\
Fixed Capital Investment & FCI & $48,300,000$ \\
Working Capital & WC & $2,420,000$ \\
Total Capital Investment & TCI & $50,700,000$ \\
Capital per Liter & CPv & 1.92 \\
\hline
\end{tabular}

The result shows reveal that the total capital investment (TCI) is worth 50.7 million dollars and showing that it would cost $\$ 1.92$ to produce a liter of fuel grade bioethanol from sorghum bagasse.

Table 12. Results for related plants in literature on total capital investment.

\begin{tabular}{lllll}
\hline Description & Code & Plant & W & H \\
& & Unit & Amount & Amount \\
\hline Total Capital Investment & TCI & M\$ & 22.64 & 34.08 \\
Capital per Litre & CPv & $\$ / L$ & 0.57 & 0.43 \\
\hline
\end{tabular}

Adapted from: Idaho Department of Water Resource Energy Division [12].

Note: $\mathrm{H}=$ Southwest, and $\mathrm{W}=$ Panhandle Plant.

This was found to be more capital intensive when compared to other plants in Idaho presented in Table 12 collected from the report of the Idaho Department of Water Resource Energy Division [12]. The survey of the literature indicated that the use of combine sugarcane-bagasse-juice $(0.34 \$ / \mathrm{L})$ and molasses $(0.10 \$ / \mathrm{L})$ less capital demand compared to sorghum bagasse [10,11].

\subsection{Operating Cost Estimation}

The estimation of operation cost is presented in Table 13. From the results presented therein, the total operating cost of the plant was estimated to be 118 million dollars. From which, the raw material cost (82.7 million dollars) was found to be mainly contributed to the cost of operation. This raw material cost entails both the sorghum bagasse, enzymes and yeast cost used in the production of bioethanol.

Table 13. Operating cost estimation results.

\begin{tabular}{lcc}
\hline Description & Symbols & Amount \\
\hline Raw Material & RM & $\$ 82,700,000$ \\
Operating Labour & OL & $\$ 89,900$ \\
Utilities & UT & $\$ 2,100,000$ \\
Direct Supervision & DS & $\$ 10,800$ \\
\hline
\end{tabular}




\begin{tabular}{lcc}
\hline Maintenance \& Repair & MR & $\$ 1,450,000$ \\
Operating Supply & OS & $\$ 188,000$ \\
Lab charges & LC & $\$ 108,000$ \\
Patent \& Royalties & PR & $\$ 2,360,000$ \\
Fixed maintenance cost & FMC & $\$ 5,950,000$ \\
Depreciation & DP & $\$ 4,830,000$ \\
Plant Overhead cost & PO & $\$ 539,000$ \\
General experience & GE & $\$ 18,200,000$ \\
Total operating cost & TOC & $\$ 118,000,000$ \\
Cost per liter & CP & $\$ 0.8253$ \\
\hline
\end{tabular}

Furthermore, it was deduced that the operation cost worth of $\$ 0.83$ would be required to produce a liter of fuel grade bioethanol. This cost was found to be more expensive to operate when compared to the plants reported by Idaho Department of Water Resource Energy Division [12], which was summarized in Table 14.

Table 14. Operating cost of related plant in literature.

\begin{tabular}{lcccc}
\hline Description & Code & Plant & H & W \\
& & (Unit) & (Amount) & (Amount) \\
\hline Cost of Manufacturing & $\mathrm{COM}$ & $\mathrm{M} \$$ & 18.18 & 34.38 \\
Cost per Litre & $\mathrm{CPv}$ & $\$ / \operatorname{gal}(\$ / \mathrm{L})$ & $2.26(0.60)$ & $1.70(0.45)$ \\
\hline
\end{tabular}

Adopted from: Idaho Department of Water Resource Energy Division [12].

Note: $\mathrm{H}=$ Southwest, and W=Panhandle Plant.

Also, the report of Oyegoke et al. [9] indicates that producing bioethanol from sugarcane bagasse $(0.50 \$ / \mathrm{L})$ is more operation cost less compared to sorghum bagasse $(0.83 \$ / \mathrm{L})$. Other reports are that of Oyegoke \& Dabai [11] and Abemi et al. [10] present $0.61 \$ / \mathrm{L}$ and $0.60 \$ / \mathrm{L}$ for the cost of operations for the processing of combine sugarcane-bagasse-juice and molasses only respectively which were found to be less expensive to the use of sorghum bagasse.

\section{CONCLUSIONS}

This study showed that that $9,408 \mathrm{~kg}$ of fuel grade bioethanol was produced from the use of 50,000 $\mathrm{kg}$ of sorghum bagasse, $6882 \mathrm{~kg}$ of enzyme, and $813 \mathrm{~kg}$ of yeast in an hour. Also, it shows that $189 \mathrm{~g}$ of fuel grade bioethanol is obtainable from a kilogram of sorghum bagasse based on the condition employed in the modeling of the process.

Cost analysis indicated that the total purchase cost of equipment was found to be 9 million dollars (where the reactor cost proved to contribute an alarming approximately $95.7 \%$ of the entire cost). Moreover, this study reveals that the total capital investment of this project is worth 50.7 million dollars, which implies that it would require a capital cost of $\$ 1.92$ to produce a liter of fuel grade bioethanol from sorghum bagasse. The total operating cost or cost of manufacturing bioethanol was found to be 118 million dollars, which indicated that the operation cost worth of $\$ 0.83$ would be required to produce a liter of fuel grade bioethanol.

The model plant was found to be cost-intensive when compared to other existing reports for bioethanol production plant. This, therefore, suggest the need for further works to look into the optimization of both cost and process to reduce the financial implications or demands.

\section{REFERENCES}

[1] Zuber, K., Anjani, K.D., Fermentation of biomass for production of ethanol: A Review, Universal Journal of Environmental Research and Technology, vol. 3, no. 1, 2013, p. 1-13.

[2] Joseph, M., Balcom, L., PRO/II simulation of bioethanol production, Invensys Operations Management, 2010. [3] Lashof, D.A., Ahuja, D.R., Relative contributions of greenhouse gas emissions to global warming. Nature, vol. 344, 1990, p. 529-531.

[4] IPCC, 2007, Climate change 2007, Synthesis report. Contribution of working groups I, II and III to the Fourth assessment report of the intergovernmental panel on climate change.

[5] Galadima, A., Garba, Z.N., Ibrahim, B.M., Almustapha, M.N., Leke, L., Adam, I.K., Biofuels production in Nigeria: The policy and public opinions, Journal of Sustainable Development, vol. 4, no. 4, 2011, p. 22-31. 
[6] Odeyemi, O., Ogunseitan, O.A., Petroleum industry and its pollution potential in Nigeria, Oil and Petroleum Pollution, vol. 2, 1985, p. 223-229.

[7] Enibe, S.O., Odukwe, A.O., Patterns of energy consumption in Nigeria, Energy Conservation and Management, vol. 30, no. 2, 1990, p. 69-73.

[8] Christiana, O., Eric, C., Economic feasibility of on-farm fuel ethanol production from Cassava, African Journal of Biotechnology, vol. 12, no. 37, 2013, p. 5618-5626.

[9] Oyegoke, T., Dabai, F.N., Jaju, A.M., Jibril, B.Y., Process modelling and economic analysis for cellulosic bioethanol production in Nigeria, 1st National Conference On Chemical Technology, held at NARICT Zaria, 2017. [10] Abemi, A., Oyegoke, T., Jibril, B.Y., Technical and economic feasibility of transforming molasses into bioethanol in Nigeria, National Engineering Conference held at Faculty of Engineering, ABU Zaria, 2018.

[11] Oyegoke, T., Dabai F.N., Techno-economic feasibility study of bioethanol production from a combined cellulose and sugar feedstock in Nigeria: 1-modeling, simulation, and cost evaluation, Nigerian Journal of Technology, vol. 37, no. 4, 2018, p. 913 - 920.

[12] Idaho Department of Water Resources, Energy Division. IDWR Annual Publication Retrieved from IDWR, 2004.

[13] Gnansounou, E., Dauriat, A., Wyman, C., Bioethanol production from sweet sorghum stalk juice with immobilized yeast, Bioresource Technology, 96, 2005, p. 985-1002.

[14] Kim, M., Day, D., Composition of sugar cane, energy cane, and sweet sorghum suitable for ethanol production at Louisiana sugar mills, Journal of Industrial Microbiology and Biotechnology, vol. 38, no. 7, 2011, p. 803-807.

[15] Mamma, D., Dimitrios, K., Fountoukidis, G., Konkios, E., Bioethanol from sweet Sorghum: Simultaneous saccharification and fermentation of carbohydrates by a mixed microbial culture, Process Biochemistry, vol. 31, no. 4, 1996, p. 377-381.

[16] Sergio, F., Alessandro, T., Reynaud, D., Lydia, L.J., Julio, B., Giacomo, T., Damiano, P., Fernando, H., Individual improvements and selective mortality shape lifelong migratory performance, Nature, vol. 515, 2014, p. 410-413.

[17] Trupti, K.S., Mohite, S.K., Magdum, C.S., Adnaik, R.S., Quantitative estimation of total phenolic content of Pueraria tuberose using different extracts by UV spectrometry, Journal of Pharmacy Research, vol. 5, no. 5, 2012, p. 2493-2495.

[18] Oyegoke, T., Review of process simulation packages, Seminar paper, Department of Chemical Engineering, Ahmadu Bello University, Zaria, 2014.

[19] Olateju, O.O., Techno-economic assessment of bioethanol production processes from sorghum Master Thesis, Federal University of Technology, Minna, 2016.

[20] Richardson, J.F., Coulson, J.M., Chemical engineering design, $4^{\text {th }}$ Ed. Oxford, UK, Butterworth - Heinemann, 2005.

[21] Sinnot, R.K., Coulson and Richardson's chemical engineering, Chemical Engineering Design, $4^{\text {th }}$ Ed., Oxford, UK, Elsevier Butterworth - Heinemann, vol. 6, 2005.

[22] Seider, W.D., Lewin, D.R., Seader J.D., Integrated process design instruction, Computer and Chemical Engineering, vol. 26, 2002, p. 295 - 306.

[23] Max, P., Klaus, T., Ronald, W., Plant design and economics for chemical engineer, $5^{\text {th }}$ Ed., New York, USA, McGraw - Hill education, 2003.

[24] Furla, P., Moya, A., Ganot, P., Sabourault, C., The transcriptomic response to thermal strength is immediate, transit, and potentiated by ultraviolet radiation in the sea anemone Anemonia Viridis, Molecular Biology, vol. 21, no. 5, 2012, p. $1158-1174$. 